\title{
ОЦІНКА ЕФЕКТИВНОСТІ ГРУПОВОГО НАВЧАННЯ З ЗАСТОСУВАННЯМ ІННОВАЦІЙНИХ ТЕХНОЛОГІЙ У СТРУКТУРІ РЕАБІЛІТАЦІЙНИХ ЗАХОДІВ У ПАЦІЄНТІВ ІЗ ЦУКРОВИМ ДІАБЕТОМ 2 ТИПУ
}

\author{
А. І. Смачило, Л. І. Іваськевич, О. М. Качунь, Л. Ф. Матвї̈в \\ Тернопільський національний медичний університет \\ імені І. Я. Горбачевського МОЗ Украӥни
}

\begin{abstract}
Сьогодення вимагає трансформації формату медицини та нових підходів до взаємовідносин лікаря/ медсестри і пацієнта, адже у повсякденному житті реальність все більше пронизує інтернет. Співпраця медика та хворого повинна грунтуватись на необхідності залучення останнього у процес лікування, перетворення його у партнера, який бере участь у реалізації важливого особистого проекту - одужання. Метою роботи було дослідження ефективності використання групових освітніх програм із застосуванням інноваційних технологій (встановлення програм і додатків на смартфонах, занять он-лайн через скайпзв’язок та ін.) у структурі реабілітаційних заходів у хворих на цукровий діабет (Цд) 2 типу. Застосовано практику групових занять з кількома пацієнтами з однією патологією, подібних за віком, особливостями перебігу хвороби, бажанням пацієнта. Метою навчання у створених групах було формування нових психологічних установок, досягнення максимальної кількості хворих, мотивованих на одужання, покращення свого загального стану, досягнення стійких кращих клініко-метаболічних показників, внесення змін у розвиток та прогресування ускладнень Цд, покращення якості життя. Після закінчення школи виявлено значне зростання відсотка пацієнтів із високою інформованістю про власну хворобу, підвищенням готовності до виконання рекомендацій лікаря/медсестри, що свідчить про ефективність таких групових освітніх програм.
\end{abstract}

\section{ASSESSMENT OF THE EFFICIENCY OF GROUP LEARNING WITH THE APPLICATION OF INNOVATIVE TECHNOLOGIES IN THE STRUCTURE OF REHABILITATION MEASURES OF PATIENTS WITH TYPE 2 DIABETES}

\author{
A. I. Smachylo, L. I. Ivasykevych, O. M. Kachun, L. F. Matviyiv
}

\section{Horbachevsky Ternopil National Medical University}

\begin{abstract}
Modernity requires a transformation of the format of medicine and new approaches to the doctor/nurse-patient relationship, because technologies has permeted every part of our life. The cooperation of the physician and the patient should be based on the necessity of involving patient in the process of treatment, to transform him into a partner who is involved in the implementation of an important personal project - recovery. The aim of the study was to investigate the efficiency of using group educational programs using of innovative technologies (installing of applications on smartphones, online classes via Skype, etc.) in the structure of the rehabilitation process of patients with type 2 diabetes. We have used the practice of group sessions with several patients with the same pathology, similar in age, features of the disease and patients desires. Aim of the training in the established groups was to form new psychological units, to achieve the maximum number of patients who are motivated to recover, to improve their general condition. Achievement of consistently better clinical and metabolic parameters, to make changes in the development and progression of complications of diabetes, to improve the quality of life. After graduation, there was a significant increase in the percentage of patients with high awareness of their illness, increasing readiness to follow doctor/nurse recommendations, which indicates the efficiency of such group educational programs.
\end{abstract}

На сьогодні експерти воОЗ відзначають, що цукровий діабет є проблемою усіх вікових категорій в усіх країнах світу. Згідно з даними Міжнародної

\footnotetext{
() А. І. Смачило, Л. І. Іваськевич, О. М. Качунь, Л. Ф. Матвіїв, 2019
}

діабетичної федерації, у світі $\epsilon$ вже більше 200 млн хворих на ЦД, а до 2025 р. їх кількість становитиме 380 млн осіб $[1,2]$. Щорічно кількість хворих на ЦД зростає на 6-7 \% і нині вже хворіє 2-4 \% населення

32 ISSN 2411-1597. МЕДСЕСТРИНСТВО. 2019. № 3 
Землі [2]. Світові тенденції зростання захворюваності на ЦД спостерігають і в Україні [1].

Традиційна модель охорони здоров'я, яка ґрунтується на принципі «розумний лікар лікує недосвідченого хворого» все більше поступається місцем новому формулюванню, де лікар чи медсестра мають освіченого пацієнта, адже у повсякденному житті реальність все більше пронизує інтернет. Усе це спонукає до трансформації самого формату медицини. Взаємовідносини лікаря чи медсестри повинні ґрунтуватися на необхідності залучення пацієнта у процес лікування, перетворення його у партнера, який бере участь у реалізації важливого особистого проекту - одужання.

якщо загальноприйнята модель стосунків медсестри і пацієнта за типом compliance передбачає пасивне підкорення і просте виконання пацієнтом ії рекомендацій, то модель concordance розглядає процес терапії як їх співпрацю і партнерство з активним залученням хворого у процес лікування. На нашу думку, наслідком такого переходу має стати поява у пацієнтів свідомої прихильності до лікування та питань профілактики хвороби.

Мета роботи: дослідити ефективність використання групових освітніх програм із застосуванням інноваційних технологій у структурі реабілітаційних заходів (шкіл здоров'я) у хворих на цукровий діабет 2 типу.

Основна частина. На базі центру первинної медико-санітарної допомоги Тернопільського району працює «Школа для хворих на цукровий діабет», в якій медичні сестри та лікарі проводять заняття з хворими на ЦД 2 типу.

Нами застосовано практику групових занять, коли лікар та медсестра проводять навчання відразу з кількома пацієнтами з подібною патологією, адже створення груп хворих одного віку з метою не лікувального, а більш інформаційного характеру, сприяє кращому сприйняттю інформації у процесі ведення дискусії, розповідей з власного досвіду членів групи [3-5].

Групові освітні заняття проводили у закритих групах (тобто після початку циклу нових учасників не приймали), кількість учасників становила 3-6 пацієнтів. Кожен цикл групової освіти складався 3 10-12 занять, тривалістю 45-60 хв із частотою один раз на тиждень. Основну групу досліджуваних склали 58 осіб обох статей віком 42-76 років, було створено 10 груп. Гендерний аспект групи пацієнтів - перевага осіб жіночої статі - 66,8 \%. Середній чоловічий склад склав 33,2 \%. У результаті проведеного анкетуван- ня виявлено, що пацієнти, старші за 37 років, мали супутні хронічні захворювання, серед яких переважала поєднана патологія: серцево-судинної системи - 70,6 \%, опорно-рухового апарату - 60,7 \%, органів травлення - 49,1\%, нервової системи - 41,1\%, сечовидільної системи - 24,9 \%, органів дихання - 20,4 \%. Аліментарно-конституційне ожиріння спостерігали у 64,2 \% пацієнтів. На основі інструментального обстеження, ретинопатію виявлено у 7,2 \% респондентів, ангіосклероз сітківки спостерігали у 40,0 \%. Діабетичну нефропатію виявлено у 4,9 \% пацієнтів. Дисциркуляторно-метаболічну енцефалопатію спостерігали у 55,1 \% пацієнтів, діабетичну полінейропатію - в 21,1 \% опитаних. Більшість пацієнтів перебувала у стані компенсації вуглеводного обміну. Переважна частина пацієнтів (84,9 \%) отримувала таблетовані цукрознижувальні препарати. У контрольну групу увійшли 16 пацієнтів, які відмовились брати участь у групових навчальних програмах.

Групові заняття проводили тривалістю не менше 1 години (індивідуальний прийом зазвичай триває 15 хв). В обов'язок медсестри входило ведення електронної медичної карти пацієнта.

Нами було рекомендовано усім пацієнтам ввести сферу медичних додатків на смартфонах у площину практичного використання лікарями та медсестрами. Також взаємодію пацієнта і медсестри розширювали через скайп-зв'язок, смартфони, що виявилось надзвичайно корисним, адже учасники групи могли самостійно вибрати час для такого спілкування.

Основні методи, які застосовувала медсестра у процесі навчання у групових заняттях:

1) метод бесіди у вигляді діалогу, монологу (емпатичне активне слухання), інтерв'ю, анкетування у створених групах;

2) метод спілкування через скайп-зв'язок, який був особливо ефективним, адже застосовували у любий зручний для учасників групи час дня за домовленістю.

У роботі використовували соціологічні, аналітичні, статистичні методи дослідження:

- анамнестичне дослідження включало структуроване інтерв'ю із вивченням спадковості, впливу контекстуальних факторів на розвиток захворювання;

- дослідження типу ставлення до хвороби й визначення типології психологічного захисту за допомогою опитувальника якості життя за опитувальником SF-36 (J. E. Ware, 1992).

Груповий освітній підхід належить до так званого навчального типу інформаційно-соціального втру- 
чання, при якому заняття ґрунтуються на принципах тематичного семінару з елементами соціальноповедінкового тренінгу [4].

Для вирішення поставленої мети використано інтегративну модель освітньої роботи, яка включала використання: інформаційного тренінгу, тренінгу формування прихильності до терапії та інтерперсональної взаємодії [5] тренінгу поліпшення комплаєнсу, проблемно-орієнтовані дискусії.

Групова робота дала можливість пацієнтам обговорити отриману інтернет-інформацію з іншими учасниками, порівняти її з власним досвідом. Важливе значення мав той факт, що учасники могли отримати важливу інформацію не тільки від медсестри та лікаря, але і від інших учасників, обмінятися з ними досвідом, разом пошукати вирішення проблем. Заняття в групі дозволяють підтримати пацієнта на стабільному рівні функціонування, допомагали пацієнту краще розуміти характер і особливості захворювання та його вплив на пацієнта і членів його родини. Не менш значущим результатом групової програми було і те, що вона сприяла створенню додаткової мережі емоційної підтримки.

На перших групових заняттях, які проводили у вигляді лекції-беседи, з 56 пацієнтів при анкетуванні виявили, що лише 42 \% опитаних мали уявлення про самоконтроль глікемії. Щоденник самоконтролю не вів жоден із пацієнтів. Про симптоми гіпоглікемії були інформовані 27,6 \% хворих. Частка респондентів, які дотримувались чіткого режиму харчування, становила 21,6 \%. Розрахунок калорійності продуктів за таблицями ніхто не проводив, респонденти мали труднощі при визначенні глікемічного індексу. 14,1% пацієнтів споживали цукрозамінники. Алкоголь вживали 23,9 \% опитаних.

Метою навчання у створених групах хворих за віком було формування нових психологічних установок, досягнення максимальної кількості хворих, мотивованих на одужання, покращення свого загального стану, досягнення стійких кращих клініко-метаболічних показників, внесення змін у розвиток та прогресування ускладнень ЦД, покращення якості життя.

Після завершення навчання більшість учасників групових занять різних вікових категорій продемонстрували підвищення рівня знань. 92,2 \% респондентів чітко відповіли на питання щодо розуміння суті хвороби цукрового діабету, його симптомів, можливих ускладнень. Глюкометри придбали і самостійно навчились контролювати глюкозу крові 69,8 \% пацієнтів. 91,2 \% хворих почали вести щоденники самоконтро- лю, проте, зауважимо, що їх значно більше було у групах хворих похилого віку. Цікавими виявились результати щодо найважливішого пункту при розвитку цукрового діабету - проблеми харчування хворого. Виявилось, що більшість учасників (94,1%) до початку освітньої програми постійно вживала у значній кількості прості вуглеводи, а після завершення навчання дотримувалась режиму та якості харчування, контроль калорійності та розрахунок «хлібних» одиниць почали здійснювати 94,2 \% пацієнтів.

Особливе враження на учасників груп справив показ відеоматеріалів з історіями конкретних хворих, демонстрацією усіх можливих наслідків прогресування хвороби - виникнення діабетичної нефропатії аж до гемодіалізу, тяжкого інсульту, інфаркту, облітеруючого ендартеріїту. Такі заняття займали значну кількість періоду навчання.

Поряд із тим, у багатьох хворих спостерігали деяку проблему при вивченні підрозділів вуглеводних («хлібних») одиниць із застосуванням таблиць, важливості у цій інформації. Виявлені труднощі при засвоєнні цих розділів програм свідчать про необхідність подальшого їх вдосконалення. Одним із можливих варіантів може бути ширше застосування таких форм навчання, як дискусія, розбір досвіду учасників навчальної програми, їх взаємодопомога, збільшення часу при розгляді цих тем.

Також у процесі організації освітніх занять ми відводили значне місце навчанню пацієнтів сучасних методів контролю цукрового діабету - показники глікованого гемоглобіну, постпрандіальної глікемії. Об'єктивні результати участі в освітніх програмах оцінювали за динамікою клініко-метаболічних параметрів, найпоказовішим у цьому відношенні став рівень глікованого гемоглобіну: до початку освітніх програм він становив 9,9 \%, а після 6 місяців навчання він склав 8,4\%.

Усім учасникам пропонували пам'ятки з наочною демонстрацією ознак гіпоглікемії та її корекції, правильного догляду за ногами, інших профілактичних дій при цукровому діабеті.

Високу зацікавленість виявили учасники при розгляді проблем лікування сучасними таблетованими цукрознижувальними препаратами, їх механізмом дії, можливої шкідливості для організму, а також у необхідності призначення у них інсулінотерапії, техніки ії проведення.

Отже, у результаті проведення групових освітніх програм серед пацієнтів із ЦД зростає рівень їх інфор- 
мованості про свою хворобу, підвищення готовності до виконання рекомендацій лікаря та медсестри, що свідчить про ефективність проведення таких програм. Роль медичної сестри у процесі навчання пацієнтів полягає в її можливості оцінити стан хворих до початку освітніх програм та у віддалений період спостереження. Медсестра-організатор визначає готовність пацієнта до навчальної інформації, залучає його у сам процес, схиляє до розуміння важливості такого навчання, встановлення власної мети хворого, підвищення його самооцінки. Крім того, у роботі сестринський персонал повинен мати знання і у галузі педагогіки та андрагогіки, що дозволяє адаптувати методи навчання в різних соціальних і освітніх рівнях пацієнтів.

\section{СПИСОК ЛІТЕРАТУРИ}

1. Уніфікований клінічний протокол первинної, екстреної, вторинної (спеціалізованої) та третинної (високоспеціалізованої) медичної допомоги. Цукровий діабет 1 типу у молодих людей та дорослих, 2014 р.

2. Адаптована Клінічна настанова «Цукровий діабет 2-го типу. Системи лікувальних заходів у відділеннях первинної та спеціалізованої медико-санітарної допомоги». Київ, 2012 (проект).

3. Інтерактивні методи навчання : навч. посіб. / за ред. П. Шевчука і П. Фенриха. - Щецін : Вид-во WSAP, 2005. $170 \mathrm{c}$.
Висновки. 1. Результати роботи продемонстрували високу ефективність використання групових освітніх програм із застосуванням інноваційних технологій у структурі реабілітаційних заходів (шкіл здоров'я) у хворих на цукровий діабет 2 типу.

2. Групова робота має свої переваги над індивідуальною, адже пацієнт одночасно $є$ і активним учасником подій і спостерігачем, що дає йому можливість набути більше інформації про проблеми своєї хвороби.

3. Реалізація навчальних програм за участю медичних сестер дасть змогу оптимізувати роботу сестринського персоналу та знизити навантаження на лікарів-ендокринологів.

4. Волканова В. Сучасні технології навчання / В. Волканова // Директор школи. - 2007. - № 37. - С. 43-45.

5. Павлова Н. К. Взаємодіюче навчання / Н. К. Павлова // Управління школою. - 2005. - № 34. - С. 12-14.

6. American Diabetes Association. Standards of Medical Care in Diabetes - 2012 // Diabetes Care. - 2012. - Vol. 35 (Suppl. 1). - S11-S59.

Отримано 03.10.19 